\title{
Examination of the Job Satisfaction of Teachers Working With Individuals in Need of Special Education With Regard to Certain Variables*
}

\author{
Mehmet Yavuz \\ Correspondence: Mehmet Yavuz, Department of special Education, Faculty of Education, Trakya University, Edirne, \\ Turkey.
}

Received: April 25, 2018

doi:10.11114/jets.v6i7.3228
Accepted: May 11, $2018 \quad$ Online Published: June 11, 2018

URL: https://doi.org/10.11114/jets.v6i7.3228

\begin{abstract}
In this study, the job satisfaction levels of teachers working with individuals in need of special education were examined with regard to certain variables. General survey model was used in the study and the study group of this research was comprised of teachers from all over Turkey who work at special education schools, integration and special education classrooms. The job satisfaction scale developed by Şahin (1999) was used in the study. The scale was developed using Google and administered online on December 08, 2017 and December 30, 2017. A total of 465 teachers participated in the study. SPSS 22 software was used for data analysis. Besides, descriptive statistics, independent sample t-test and one-way ANOVA test were used for data analysis. As for the results of the study, while no statistically significant difference was found in terms of gender, number of working years, considered income level, and age, statistically significant differences were observed according to salary, receiving support from colleagues, receiving praise from administrators, finding working at special education schools convenient variables.
\end{abstract}

Keywords: job satisfaction, individuals with special education needs, special education

\section{Introduction}

Job satisfaction, depending on the job, can be defined as happiness, fulfillment or the opposite as unhappiness or discontentment at a workplace where one can receive a reward (Churchill, Ford \& Walker, 1974). According to Duxbury, Armstrong, Drew \& Henly (1984), job satisfaction is the emotional behaviour that is developed as a result of a person's subjective evaluation towards his job and job environment. People work to earn their livings and they may have certain attitudes towards their jobs. When they like their jobs and develop a positive attitude, it is called job satisfaction and the opposite is called dissatisfaction (Eğinli, 2009).

Job satisfaction is very important for employees. Therefore, all organizations wish their employees be satisfied with their jobs. In this context, research has shown that job satisfaction affects attendance, income of the workplace, work performance, behaviour and attitude against workplace (Oshagbemi, 2003). Izgar views job satisfaction as an emotional state where the individual feels happy and enjoys working (2000). All individuals must be happy with their jobs. However, employees often find themselves in some unfavourable situations such as pressure, stress and similar on in their work. These undesirable circumstances can affect their health negatively and trigger some illnesses (Faragher, Cass \& Cooper, 2005). Employees' happiness is an important variable because our jobs are not only a way of income but also a part of our social lives (Sharma \& Jyoti, 2009).

Job satisfaction can be affected by individual and external factors (Başaran, 2000; Ghavifekr \& Pillai, 2016). While the salary, qualities of the job, promotion opportunities, working conditions, spirits of the employee and relations with the managerial staff constitute the external factors, gender, work, living environment, education level, duration of work and personality are the individual factors (Başaran, 2000).

Teachers' job satisfaction can be defined as their positive or negative attitude towards students or school (Vural, 2004) and it can be affected by numerous factors such as administrators, colleagues (Ghavifekr \& Pillai, 2016; Jackson, Schwab, \& Schuler, 1986;Kağan, 2005), working conditions (Ghavifekr \& Pillai, 2016;Jackson, Schwab \& Schuler, 1986), salary, responsibilities, the job, security, appreciation (Belias 2014; Waters 2013), working hours and teachers' personal qualities (Jackson, Schwab, \& Schuler, 1986).

${ }^{*}$ Published 1st International Congress on New Horizons in Education and Social Sciences as summary text. 
Teachers' high job satisfaction is a factor, which promotes the quality of education (Şahin, 2013). One of the most important issues dealt with in today's schools is how to increase the quality of education. Therefore, teachers' job satisfaction should be increased (Ghavifekr \& Pillai, 2016). As their job satisfaction increases, they feel happier and reflect it to their students positively. Thus, the more the quality of education increases, the more successful students will be (Şahin, 2013). Job satisfaction may also contribute to improve teachers' skills and abilities. To ensure this, they should work in a positive atmosphere (Ghavifekr \& Pillai, 2016). In other words, working in a pleasant environment has a positive effect on job satisfaction (Tran \& Le, 2015). In the light of literary review, it is possible to conclude that teachers' happiness at work affects their job satisfaction positively (Akhtara, Hashmib, \& Naqvic, 2010).

Controlling individuals who have inabilities may be difficult and teachers may face some problems while educating them. This is the reason why some of them are unhappy with working at such schools (Başaran, 2001). Teachers who work with people with inabilities are usually stressful and present burnout syndrome more than their colleagues working with healthy children (Girgin \& Baysal, 2005a). While the literature was reviewed, few studies, either domestic or foreign, that focus on the job satisfaction of teachers of special education were found. The study carried out by Akkaş (2017) is an example of the studies regarding the job satisfaction levels of teachers teaching in special education classes in Turkey. In another study carried out in Turkey, Mistan (2017) has studied teachers' job satisfaction and their burnout syndrome; Yaman (2015), on the other hand, examined the job satisfaction of administrative staff working at vocational training centres. In another research which was based on Turkish context, Güneş (2016) studied job satisfaction levels and burnout syndrome of trainers working with disabled athletes and in a similar study, Yiğit (2007) sought to address job satisfaction level, burnout syndrome and mental health conditions of teachers working at special education schools. As for the studies carried out abroad, several studies on teachers working at special education schools were found (Cummings, 1994; Mastrantuono, 2015; Ketheeswarani, 2018; Shourbagi \& Bakkar, 2015; Stempien \& Loeb, 2002; Strydom, Nortjé, Beukes, Esterhuyse \& van der Westhuizen, 2012; Wangari and Orodho, 2014). To find out more about the issue, this study aims to find out the answers to the following questions;

1. What are the job satisfaction levels of teachers working at special education schools?

2. Do the job satisfaction levels of teachers working at special education schools present any differences with regard to the gender variable?

3. Do the job satisfaction levels of teachers working at special education schools show any differences considering the salary variable?

4. Do the job satisfaction levels of teachers working at special education schools point out any differences regarding the variable of the support they get from their colleagues?

5. Do the job satisfaction levels of teachers working at special education schools have any differences in terms of the appraisal they get from their administrators?

6. Do the job satisfaction levels of teachers working at special education schools display any differences according to the variable of considering working at special education schools convenient?

7. Do the job satisfaction levels of teachers working at special education schools present any differences with regards to years of experience variable?

8. Do the job satisfaction levels of teachers working at special education schools point out any differences regarding their income levels variable?

9. Do the job satisfaction levels of teachers working at special education schools have any differences concerning their age variable?

\section{Method}

Research model, working groups, data collection tool and data analysis will be given in this section.

\subsection{Research Model}

In the present paper, descriptive survey model is used. Descriptive models are the ones where research is carried out on a sample or samples taken out from large numbers of elements from the whole population (Karasar, 1994).

\subsection{Working Group}

This research was carried out on a total of 465 teachers working at special education schools across Turkey and volunteer teachers who accepted to take part in the study during 2017-2018 education year. Demographic data was given in Table 1. 
Table 1. Demographic data of the teachers

\begin{tabular}{|c|c|c|}
\hline Gender & $\mathbf{N}$ & $\%$ \\
\hline Male & 172 & 37 \\
\hline Female & 293 & 63 \\
\hline Do you get support from your colleagues? & $\mathbf{N}$ & $\%$ \\
\hline Yes & 345 & 74 \\
\hline No & 120 & 26 \\
\hline Do you think it is convenient to work at special education schools? & $N$ & $\%$ \\
\hline Yes & 390 & 84 \\
\hline No & 75 & 16 \\
\hline Years of work & $\mathbf{N}$ & $\%$ \\
\hline $1-10$ & 341 & 73 \\
\hline $11-20$ & 78 & 17 \\
\hline 31 and up & 46 & 10 \\
\hline Your Institution & $\mathbf{N}$ & $\%$ \\
\hline Education Application & 178 & 38 \\
\hline Work Application & 102 & 22 \\
\hline Vocational Training & 41 & 9 \\
\hline Special Education Class & 144 & 31 \\
\hline Are your earnings sufficient? & $\mathbf{N}$ & $\%$ \\
\hline Yes & 69 & 15 \\
\hline No & 396 & 85 \\
\hline Do you get appraisal from your administrators? & $N$ & $\%$ \\
\hline Yes & 268 & 58 \\
\hline No & 197 & 42 \\
\hline Your Subject of Teaching & $N$ & $\%$ \\
\hline Special Education & 313 & 67 \\
\hline Other & 152 & 33 \\
\hline Where do you see yourself in terms of income? & $N$ & $\%$ \\
\hline Bottom & 135 & 29 \\
\hline Middle & 306 & 66 \\
\hline Top & 24 & 5 \\
\hline Age & $\mathbf{N}$ & $\%$ \\
\hline Under 30 & 310 & 67 \\
\hline $31-40$ & 107 & 23 \\
\hline $41-50$ & 35 & 7 \\
\hline 51 and up & 13 & 3 \\
\hline
\end{tabular}

\subsection{Data Collection Tool}

In this study, a job satisfaction scale proposed by Şahin (1999) was used as the data collection tool. The scale consists of 42 questions and 6 sub dimensions such as the Job, Administration, Salary, Success-Appreciation-Recognition, Relations among Individuals, Parent Student Apathy. Just as the Cronbach Alpha value of the scale, the value of the present study is also .91. The scale was organised as a rating scale with triple ranking, where each "yes" is 3 points; each "maybe" is 2 points; each "no" is 1 point. Negative questions have the opposite scaling. Since the scale consists of two intervals and three choices, the scale was divided by interval number to find the arithmetic mean and the result was calculated as . $<066$. One point was added to it, and a value between $1-1.66$ was obtained which represents "not satisfied" and 2.34 - 3.00 to represent "satisfied". To collect the demographic data, an information sheet was prepared by the researcher. This form includes information regarding gender, age, years of work experience, major (field of work), desired amount of income, place of work, "Is your salary enough?", "Do you get support from your colleagues?", "Do you get appraisal from your administrators?", "Do you think it is convenient to work at special education schools?".

\subsection{Collection and Evaluation of Data}

In order to collect data for the present study a Google scale was formed. This form was kept active for the use of participants between 08 and 30 December 2017. The researcher asked the participants working at special education schools to volunteer in the study sending them the link of the scale formed on Google to their e-mails and Facebook messenger accounts. Besides, the researcher sent the link to the participants also working at special education schools via Whatsapp when he could not reach their mail and messenger accounts. For the analysis of the data SPSS 22 (The Statistical Package for the Social Sciences) programme was used. In addition, to checking the normal distribution Kolmogorov-Smirnov and Shapiro-Wilk tests were utilized. However, both Kolmogorov-Smirnov and Shapiro-Wilk tests showed that there is no normal distribution. Therefore, to test the normal distribution of the data, kurtosis and skewness values were evaluated and as a result of this evaluation, they were detected to be within the limit, which is 
\pm 1.96 . According to Tabachnick \& Fidell (2007) a value of \pm 1.96 shows that the data is distributed normally. After finding out that the data was normally distributed, parametric tests were employed in this study. For the analysis of the data, descriptive statistics, independent samples t-test and one-way ANOVA test were used. As the post ANOVA test, LSD tests were implemented. During the analysis of data, the statistical meaningfulness was taken as .05.

\section{Findings}

In this section, charts and interpretations of descriptive statistical data and findings were presented. Findings were ordered in accordance with sub problem ordering.

Table 2. Descriptive statistical data related to burnout level of teachers

\begin{tabular}{lccccc}
\hline & $\mathbf{N}$ & $\bar{x}$ & $\mathrm{~m}$ & Ss & $\bar{x} / \mathrm{m}$ \\
\hline Job Satisfaction Scale & 465 & 2,11 & 42 &, 13 & 2,12 \\
Sub Dimensions of the Scale & & & & & \\
The job & 2,47 & 7 &, 41 & 2,47 \\
Administration & 2,22 & 11 &, 52 & 2,27 \\
Salary & 1,73 & 6 &, 41 & 1,74 \\
Relations among individuals & 2,30 & 5 &, 54 & 2,30 \\
Success-Appreciation-Recognition & 2,52 & 7 &, 35 & 2,53 \\
Parent Student Apathy & 1,82 & 6 &, 49 & 1,82 \\
\hline
\end{tabular}

Table 3. Results of unpaired t-test based on gender variable

\begin{tabular}{lccccccc}
\hline \multicolumn{1}{c}{ Gender } & & $N$ & $\bar{x}$ & $S S$ & $t$ & $s d$ & $p$ \\
\hline \multirow{2}{*}{ Job satisfaction scale } & Male & 172 & 2,22 &, 30 &, 50 & 463,00 &, 618 \\
& Female & 293 & 2,21 &, 34 & & & \\
The job & Male & 172 & 2,45 &, 41 &,- 98 & 463,00 &, 327 \\
& Female & 293 & 2,49 &, 41 & & & \\
Administration & Male & 172 & 2,31 &, 48 & 1,31 & 392,25 &, 191 \\
& Female & 293 & 2,25 &, 54 & & & \\
Salary & Male & 172 & 1,78 &, 40 & 1,79 & 463,00 &, 074 \\
Relations among individuals & Female & 293 & 1,71 &, 43 & & & \\
& Male & 172 & 2,33 &, 51 &, 86 & 463,00 &, 390 \\
\multirow{5}{*}{ Success-Appreciation-Recognition } & Memale & 293 & 2,29 &, 57 & & & \\
& Male & 158 & 2,47 &, 37 & $-2,66$ & 463,00 &, $008^{*}$ \\
Parent Student Apathy & Female & 290 & 2,56 &, 34 & & & \\
& Male & 158 & 1,84 &, 46 &, 70 & 463,00 &, 486 \\
& Female & 290 & 1,81 &, 51 & & & \\
\hline
\end{tabular}

$\mathrm{P}^{*}<0,05$

Job satisfaction among teachers depending on gender variable shows significant results $(t=, 618 ; p>0,05)$ (Table 3 ). When sub dimensions of the scale were examined, the job presents significant difference $(t=, 327 ; p>0,05)$; on the other hand, there is not a meaningful difference between administration $(t=, 191 ; p>0.05)$, salary $(t=, 074 ; p>0.05)$, relations among individuals $(\mathrm{t}=, 390 ; \mathrm{p}>0.05)$, and parent student apathy $(\mathrm{t}=, 486 ; \mathrm{p}>0.05)$. Despite this, Success-Appreciation-Recognition has a significant difference $(\mathrm{t}=, 008 ; \mathrm{p}<0.05)$. As for the gender variable, the data (female: $=2,56$; male: $=2,47$ ) suggests meaningful difference in favour of the female teachers.

Table 4. Salary variable unpaired t-test results

\begin{tabular}{lllllllll}
\hline Is your salary enough? & & $N$ & $\bar{x}$ & $S S$ & $t$ & $s d$ & $p$ \\
\hline Job satisfaction scale & Yes & 69 & 2,36 &, 32 & 4,19 & 463,00 &, $000^{*}$ \\
& No & 396 & 2,18 &, 32 & & & \\
The job & Yes & 69 & 2,66 &, 37 & 4,08 & 463,00 &, $000^{*}$ \\
& No & 396 & 2,44 &, 41 & & & \\
Administration & Yes & 69 & 2,35 &, 48 & 1,37 & 463,00 &, 170 \\
& No & 396 & 2,26 &, 53 & & & \\
Salary & Yes & 69 & 2,25 &, 41 & 12,69 & 463,00 &, $000^{*}$ \\
Relations among individuals & No & 396 & 1,65 &, 35 & & & \\
& Yes & 69 & 2,36 &, 54 &, 86 & 463,00 &, 388 \\
& No & 396 & 2,29 &, 55 & & & \\
Success-Appreciation-Recognition & Yes & 69 & 2,58 &, 36 & 1,25 & 463,00 &, 211 \\
& No & 396 & 2,52 &, 35 & & & \\
Parent Student Apathy & Yes & 69 & 1,90 &, 51 & 1,44 & 463,00 &, 150 \\
\hline
\end{tabular}

$\mathrm{P}^{*}<0,05$

As seen in Table 4, job satisfaction of the teachers according to the salary variable presents a significant difference 
$(\mathrm{t}=, 000 ; \mathrm{p}<0,05)$. When the sub dimensions were investigated, the job $(\mathrm{t}=, 000 ; \mathrm{p}<0,05)$ and salary $(\mathrm{t}=, 000 ; \mathrm{p}<0,05)$ also indicate a significant difference. However, administration $(t=, 170 ; p>0.05)$, relations among individuals $(t=, 388 ; p>0.05)$, Success-Appreciation-Recognition ( $\mathrm{t}=, 211 ; \mathrm{p}>0.05)$, and parent student apathy $(\mathrm{t}=, 150 ; \mathrm{p}>0.05)$ do not have a significant difference in the sub dimensions. There are significant differences in teachers' job satisfaction results among those who find their salary enough (yes=2,36; no=2,18). The job (yes=2,66; no=2,44), salary (yes=2,25; no= 1,65) suggests a significant difference among the teachers who consider their salary enough.

Table 5. Do you get support from your colleagues? variable unpaired t-test results

\begin{tabular}{lccccccc}
\hline \multirow{2}{*}{ Do you get support from your colleagues? } & $N$ & $\bar{x}$ & $S S$ & $t$ & $s d$ & $p$ \\
\hline \multirow{2}{*}{ Job satisfaction scale } & Yes & 345 & 2,28 &, 29 & 7,88 & 463,00 &, $000^{*}$ \\
\multirow{3}{*}{ The job } & No & 120 & 2,02 &, 35 & & & \\
& Yes & 345 & 2,54 &, 38 & 5,80 & 179,61 &, $000^{*}$ \\
Administration & No & 120 & 2,28 &, 45 & & & \\
& Yes & 345 & 2,38 &, 47 & 7,48 & 185,07 &, $000^{*}$ \\
Salary & No & 120 & 1,96 &, 54 & & & \\
\multirow{2}{*}{ Relations among individuals } & Yes & 345 & 1,76 &, 42 & 2,00 & 463,00 &, 046 \\
& No & 120 & 1,67 &, 41 & & & \\
\multirow{5}{*}{ Success-Appreciation-Recognition } & Yes & 345 & 2,41 &, 50 & 6,65 & 183,28 &, $000^{*}$ \\
& No & 120 & 2,01 &, 58 & & & \\
\multirow{2}{*}{ Parent Student Apathy } & Yes & 345 & 2,58 &, 33 & 5,71 & 463,00 &, $000^{*}$ \\
& No & 120 & 2,38 &, 36 & & & \\
& Yes & 345 & 1,84 &, 49 & 1,40 & 463,00 &, 162 \\
& No & 120 & 1,77 &, 49 & & & \\
\hline
\end{tabular}

$\mathrm{P}^{*}<0,05$

There is a significant difference in teachers' job satisfaction on the basis of their support from colleagues $(t=, 000 ; p<0,05)$ (Table 5). When the sub dimensions were examined closely, that is, the job ( $\mathrm{t}=, 000 ; \mathrm{p}<0,05)$, administration $(\mathrm{t}=, 000 ; \mathrm{p}<0,05)$, salary $(\mathrm{t}=, 000 ; \mathrm{p}<0,05)$, relations among individuals $(\mathrm{t}=, 000 ; \mathrm{p}<0,05)$ success appreciation recognition $(\mathrm{t}=, 000 ; \mathrm{p}<0,05)$, it is evident that they have statistically significant differences. However, there is not a significant difference in parent student apathy ( $\mathrm{t}=, 162 ; \mathrm{p}>0.05)$. According to teachers' general job satisfaction, those who receive support from colleagues indicate a significant difference (yes $=2,13 ; \mathrm{no}=2,09$ ). For the teachers who receive support, the sub dimensions of the scale also present significant difference; namely, the job (yes= 2,54;no $=2,28)$, salary (yes $=1,76 ; \mathrm{no}=1,67$ ), relations among individuals (yes=2,41;no $=2,01$ ) and success appreciation recognition (yes=3,58;no=2,38).

Table 6. Do you get support from administrators? Variable unpaired t-test results

\begin{tabular}{llcccccc}
\hline $\begin{array}{c}\text { Do you get appraisal from your } \\
\text { administrators? }\end{array}$ & & $N$ & $\bar{x}$ & $S S$ & $t$ & $s d$ & $p$ \\
\hline \multirow{2}{*}{ Job satisfaction scale } & Yes & 268 & 2,35 &, 27 & 11,97 & 463,00 &, $000^{*}$ \\
& No & 197 & 2,03 &, 31 & & & \\
The job & Yes & 268 & 2,60 &, 34 & 7,58 & 359,05 &, $000^{*}$ \\
& No & 197 & 2,31 &, 44 & & & \\
Administration & Yes & 268 & 2,53 &, 37 & 15,05 & 352,52 &, $000^{*}$ \\
& No & 197 & 1,91 &, 48 & & & \\
Salary & Yes & 268 & 1,78 &, 40 & 2,88 & 463,00 &, $004^{*}$ \\
Relations among individuals & No & 197 & 1,67 &, 43 & & & \\
& Yes & 268 & 2,44 &, 49 & 6,62 & 463,00 &, $000^{*}$ \\
& No & 197 & 2,12 &, 57 & & & \\
Success-Appreciation-Recognition & Yes & 268 & 2,63 &, 32 & 7,56 & 463,00 &, $000^{*}$ \\
& No & 197 & 2,39 &, 34 & & & \\
Parent Student Apathy & Yes & 268 & 1,88 &, 50 & 2,72 & 463,00 &, $007^{*}$ \\
& No & 197 & 1,75 &, 47 & & & \\
\hline
\end{tabular}

$\mathrm{P}^{*}<0,05$

There is a significant difference in teachers' job satisfaction with regard to their getting appraisal from their administrators $(\mathrm{t}=, 000 ; \mathrm{p}<0,05)$ (Table 6). When the sub dimensions were analyzed, the job $(\mathrm{t}=, 000 ; \mathrm{p}<0,05)$, administration $(\mathrm{t}=, 000 ; \mathrm{p}<0,05)$, salary $(\mathrm{t}=, 004 ; \mathrm{p}<0,05)$, relations among individuals $(\mathrm{t}=, 000 ; \mathrm{p}<0,05)$ success appreciation recognition $(\mathrm{t}=, 000 ; \mathrm{p}<0,05)$ and parent student apathy $(\mathrm{t}=, 007 ; \mathrm{p}<0.05)$ have statistically significant differences. According to teachers' general job satisfaction, those who get appraisal from administrators indicate a significant difference (yes=2,35; no=2,03). As for the teachers who receive support, sub dimensions of the scale point out a significant difference too; that is, the job (yes $=2,60 ; \mathrm{no}=2,31$ ), administrators (yes $=2,53 ; \mathrm{no}=1,91)$ salary (yes= 1,$78 ; \mathrm{no}=1,67$ ), relations among individuals (yes $=2,44 ; \mathrm{no}=2,12$ ) and success appreciation recognition (yes $=2,63 ; \mathrm{no}=$ 2,39 ) and parent student apathy (yes= 1,$88 ;$ no $=1,75$ ). 
Table 7. "Do you think it is convenient to work at special education schools?" variable unpaired t-test results

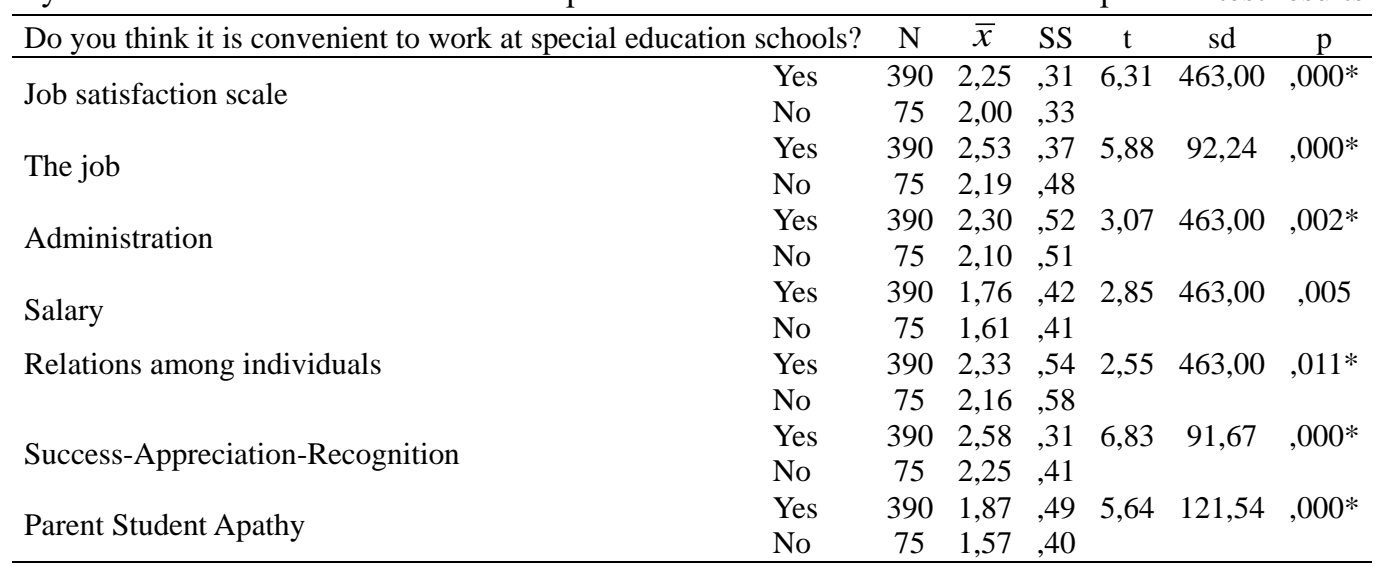

$\mathrm{P} *<0,05$

As seen in Table 7, there is a significant difference in teachers' job satisfaction regarding their opinion about working at special education schools $(\mathrm{t}=, 000 ; \mathrm{p}<0,05)$. Concerning the sub dimensions, the job $(\mathrm{t}=, 000 ; \mathrm{p}<0,05)$, administration $(\mathrm{t}=, 002 ; \mathrm{p}<0,05)$, salary $(\mathrm{t}=, 005 ; \mathrm{p}<0,05)$, relations among individuals $(\mathrm{t}=, 011 ; \mathrm{p}<0,05)$ success appreciation recognition $(\mathrm{t}=, 000 ; \mathrm{p}<0,05)$ and parent student apathy $(\mathrm{t}=, 000 ; \mathrm{p}<0.05)$ suggest statistically significant differences. Based on the teachers' opinion about working at special education schools, those who think positively about their work indicate a significant difference (yes=2,25; no=2,00). Moreover, for the teachers who think positively, the sub dimensions of the scale present significant differences as well; namely, the job (yes= 2,53; no $=2,19)$, administrators $(\mathrm{yes}=2,30 ; \mathrm{no}=1,10)$ salary $($ yes $=1,76 ; \mathrm{no}=1,61)$, relations among individuals $(\mathrm{yes}=2,33 ; \mathrm{no}=2,16)$ and success appreciation recognition (yes $=2,58 ; \mathrm{no}=2,25)$ and parent student apathy (yes=1,87;no= 1,57).

Table 8. Years of work ANOVA test results

\begin{tabular}{|c|c|c|c|c|c|}
\hline & Years of work & $\mathrm{N}$ & SS & $\mathrm{f}$ & $\mathrm{p}$ \\
\hline \multirow{3}{*}{ Job satisfaction } & Between 1-10 years & 3412,22 & 2,331 &, 076 &, 342 \\
\hline & Between 11-20 years & 782,16 & ,33 & & \\
\hline & 21 years and up & 462,21 & ,33 & & \\
\hline \multirow{3}{*}{ The Job } & Between 1-10 years & 3412,50 & ,414 & +,890, & ,008* \\
\hline & Between 11-20 years & 782,34 & ,42 & & \\
\hline & 21 years and up & 462,50 & 39 & & \\
\hline \multirow{3}{*}{ Administration } & Between 1-10 years & 3412,27 &, 52 & ,003 & ,997 \\
\hline & Between 11-20 years & 782,27 &, 54 & & \\
\hline & 21 years and up & 462,26 &, 51 & & \\
\hline \multirow{3}{*}{ Salary } & Between 1-10 years & 3411,75 & 431 & 1,644 &, 194 \\
\hline & Between 11-20 years & 781,66 & 42 & & \\
\hline & 21 years and up & 461,75 & ,34 & & \\
\hline \multirow{3}{*}{ Relations among individuals } & Between 1-10 years & 3412,32 &, 54 & ,886 & ,413 \\
\hline & Between 11-20 years & 782,30 &, 56 & & \\
\hline & 21 years and up & 462,20 &, 54 & & \\
\hline \multirow{2}{*}{ Success Appreciation Recognition } & Between 1-10 years & 3412,55 & 342 & 2,559 & ,078 \\
\hline & Between 11-20 years & 782,45 & ,36 & & \\
\hline \multirow{4}{*}{ Parent Student Apathy } & 21 years and up & 462,52 & ,39 & & \\
\hline & Between 1-10 years & 3411,82 & 49 & ,408 & 665 \\
\hline & Between 11-20 years & 781,81 &, 52 & & \\
\hline & 21 years and up & 461,88 & ,47 & & \\
\hline
\end{tabular}

$\mathrm{P}^{*}<0,05$

As far as the years of work variable is concerned, there is not a significant difference in teachers' job satisfaction $(\mathrm{f}=, 342 ; \mathrm{p}>0.05)$ (Table 8). Considering the sub dimensions of the job satisfaction scale, which are administration $(\mathrm{f}=, 997 ; \mathrm{p}>0.05)$, salary $(\mathrm{f}=, 194 ; \mathrm{p}>0.05)$, relations among individuals $(\mathrm{f}=, 413 ; \mathrm{p}>0.05)$, success appreciation recognition $(\mathrm{f}=, 078 ; \mathrm{p}>0.05)$ and parent student apathy $(\mathrm{f}=, 665 ; \mathrm{p}>0.05)$, they do not indicate a significant difference, either. However, the job variable shows a significant difference in its sub dimension, $(f=, 008 ; p<0.05)$. The results of LSD test aiming to find the difference stemming from years of work were given in Table 9. 
Table 9. LSD test regarding the sub dimension of the years of work variable

\begin{tabular}{cllcc}
\hline Job Satisfaction & \multicolumn{1}{c}{ Years of work } & \multicolumn{1}{c}{ Years of Work } & Mean Difference & p \\
\hline & $\begin{array}{l}\text { Between 1-10 } \\
\text { years }\end{array}$ & Between 11-20 years &, $159^{*}$ &, 002 \\
& & 21 years and up &, 001 &, 982 \\
Sub dimension of the job & Between 11-20 & Between 1-10 years &,$- 159^{*}$ &, 002 \\
& years & 21 years and up &,$- 158^{*}$ &, 039 \\
& \multirow{2}{*}{ 21 years and up } & Between 1-10 years &,- 001 &, 982 \\
& & Between 11-20 years &, $158^{*}$ &, 039 \\
\hline
\end{tabular}

$\mathrm{P} *<0,05$

When the LSD Test results were taken into consideration, it can be seen that there is a difference in sub dimensions of 11-20 years, 1-10 years and 21 years and up (Table 9). A significant relation between the teachers with 1-10 years of experience and those with an experience of 21 years and up was not observed. In the sub dimension of the job, when 1-10 years was compared with 21 years and up variable, there is a significant difference among teachers with 1-10 years of experience. There is also a significant difference among ones with 21 years and up, compared with the ones with 11-20 years of experience.

Table 10. ANOVA test results according to of the considered income level variance?

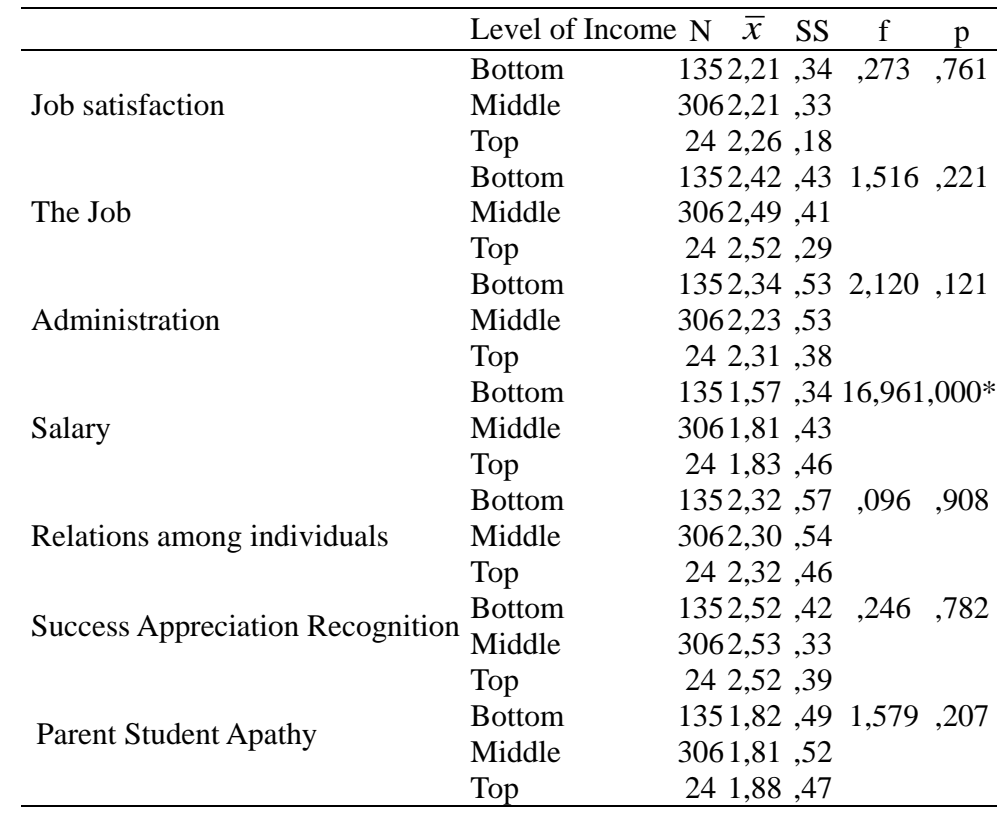

$\mathrm{P}^{*}<0,05$

As for the data presented in Table 10, a significant difference was found in teachers' job satisfaction based on their opinion about where they see themselves in terms of their incomes $(\mathrm{f}=, 761 ; \mathrm{p}>0.05)$. When the sub dimensions of the job satisfaction scale were investigated, no significant differences were found regarding the job ( $\mathrm{f}=, 221 ; \mathrm{p}>0.05)$, administration ( $\mathrm{f}=, 121 ; \mathrm{p}>0.05)$, relations among individuals $(\mathrm{f}=, 908 ; \mathrm{p}>0.05)$, success appreciation recognition $(\mathrm{f}=, 782 ; \mathrm{p}>0.05)$ and parent student apathy $(\mathrm{f}=, 207 ; \mathrm{p}>0.05)$ variables. However, as of the salary variable, there is a significant difference $(\mathrm{f}=, 000 ; \mathrm{p}<0.05)$. The results of the LSD test were given in Table 11.

Table 11. The results of the sub dimensions of the LSD test concerning the question "Where do you see yourself in terms of your income?"

\begin{tabular}{|c|c|c|c|c|}
\hline \multicolumn{4}{|c|}{ Job Satisfaction (I) income level(J) income level Mean Difference } & $\mathbf{p}$ \\
\hline \multirow{6}{*}{ Salary } & \multirow[t]{2}{*}{ Bottom level } & Middle level &,$- 240 *$ & $, 042,000$ \\
\hline & & Top level &,$- 261 *$ & ,090,004 \\
\hline & \multirow[t]{2}{*}{ Middle level } & Bottom level &, $240 *$ & $, 042,000$ \\
\hline & & Top level &,- 021 & ,086,804 \\
\hline & \multirow[t]{2}{*}{ Top level } & Bottom level & ,261* & ,090,004 \\
\hline & & Middle level &, 021 & $, 086,804$ \\
\hline
\end{tabular}

$\mathrm{P}^{*}<0,05$

The results of the job satisfaction LSD test based on the teachers' salary levels were indicated in Table 11. There is a 
significant relation between bottom level and middle and top levels of incomes. In this study, it was revealed that there is no significant relation between middle and top levels of income. However, according to the results of the sub dimensions of the LSD Test, there is a significant difference between the top level when compared with the bottom and middle levels. Similarly, comparing the bottom and middle levels, there is a significant difference in favour of the middle level.

Table 12. Age variable ANOVA Test Results

\begin{tabular}{|c|c|c|c|}
\hline & $\mathbf{N} \bar{x}$ & SS & $\mathbf{p}$ \\
\hline \multirow{4}{*}{ Job Satisfaction } & Under $30 \quad 3102,21$ & ,331 & $1,273,283$ \\
\hline & Between 31-401072,18 & 33 & \\
\hline & Between 41-50 35 2,27 & 29 & \\
\hline & 50 up $\quad 132,34$ & 25 & \\
\hline \multirow{4}{*}{ The Job } & Between 31-403102,49 & ,431 & $1,377,249$ \\
\hline & Between 41-501072,42 & ,38 & \\
\hline & 50 up $\quad 352,42$ & 40 & \\
\hline & Between 31-40 132,59 & 31 & \\
\hline \multirow{4}{*}{ Administration } & Between 41-503102,25 &, 521 & $1,657,176$ \\
\hline & 50 up $\quad 1072,25$ &, 54 & \\
\hline & Between 31-40 35 2,39 & ,48 & \\
\hline & Between 41-50 132,50 &, 50 & \\
\hline \multirow{4}{*}{ Salary } & 50 up $\quad 3101,76$ & ,421 & $1,237,296$ \\
\hline & Between 31-40107 1,67 & ,43 & \\
\hline & Between 41-50 35 1,76 & ,45 & \\
\hline & 50 up $\quad 131,74$ &, 25 & \\
\hline \multirow{4}{*}{ Relations Among Individuals } & Between 31-403102,29 &, 56 & 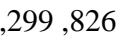 \\
\hline & Between 41-501072,31 &, 53 & \\
\hline & 50 up $\quad 352,37$ &, 52 & \\
\hline & Between 31-40 13 2,38 & 40 & \\
\hline \multirow{3}{*}{ Success Appreciation Recognition } & Between 41-503102,54 & 35 & 427 \\
\hline & 50 up $\quad 1072,49$ & ,36 & \\
\hline & Between 31-40 35 2,55 & ,34 & \\
\hline \multirow{5}{*}{ Parent student apathy } & Between 41-50 13 2,64 & 33 & \\
\hline & 50 up $\quad 3101,80$ & ,481 & $1,330,264$ \\
\hline & Between 31-40107 1,82 &, 50 & \\
\hline & Between 41-50 351,96 & ,55 & \\
\hline & 131,95 & ,39 & \\
\hline
\end{tabular}

When the data presented in Table 12 was examined, there is not a significant difference on the basis of teachers' age variable ( $\mathrm{f}=, 283 ; \mathrm{p}>0.05$ ). Furthermore, analyzing the sub dimensions of the scale comprehensively, it was detected that there is not a significant difference, either.

\section{Findings and Discussion}

In the light of the findings obtained in this study, it can be concluded that job satisfaction levels among special education teachers could be said to be average, that is, they find their jobs partly satisfactory. Investigating the literature, it is seen that the research carried out on special education teachers has revealed similar results (Abushaira, 2012; Stempien \& Loeb, 2002; Strydom et al., 2012; Yiğit, 2007). Shourbagi \& Bakkar (2015) and Wangari \& Orodho (2014) carried out a research on special education teachers and found that their job satisfaction levels were low. Akkaş (2017) and Ketheeswaran (2018); however, revealed that job satisfaction among special education teachers was high.

As far as the research findings of this study concerned, a significant difference among the teachers on the basis of gender variable was not detected. The literary review regarding the issue revealed that the results found in the studies were similar. For example, Abushaira (2012), Eichinger (2000) and Strydom et al. (2012) were not able to find significant differences based on gender variables. Like others, Karaçam (2017), in his study on administrative staff of school for disabled students, did not find significant differences based on gender. Neither Şahin (2013) who worked with primary school teachers nor Tan (2003) who worked with high school teachers was able to find a significant difference in their studies. However, there are also studies with different findings. Aydın, Uysal \& Sarıer (2012), found higher values for male teachers' job satisfaction levels in their meta-analysis. Similarly, Clark (1997), Liu \&Ramsey (2008), Newstrom \& Davis (1997) and a report by OECD (2014) pointed out that male teachers' job satisfaction levels were higher.

The results of this study did not show a significant difference in terms of gender variable among the teachers who work at special education schools. This result may be assumed to stem from both genders' performing the same duties and sharing the same responsibilities at work. Only the levels of success, appreciation and recognition were found to be higher in the sub dimension of women's results. In the literature concerning the same issue, there exist some studies 
where women's job satisfaction levels were detected to be higher. For example, Akkaş (2017) and Yiğit (2007) found that job satisfaction levels of women are higher on the basis of gender differences. Moreover, Bogler (2002), Clark (1997), Kumaş \& Deniz (2010) and Şahin (1999) also suggested that women's job satisfaction levels were higher. The relatively higher levels of job satisfaction of success, appreciation and recognition among women may be attributed to the idea that teaching is widely considered as a suitable job for women (Kumaş \& Deniz, 2010).

According to the general findings of the job satisfaction scale, the level of job satisfaction was found to be higher among teachers who receive higher salaries in this study. Similarly, Ketheeswarani (2018) and Shourbagi (2015) revealed some significant relations between job satisfaction and salary variable. According to a research carried out by Filiz (2014) similar results were also obtained; teachers who get higher salaries tend to have a higher level of job satisfaction. 65 (14\%) of the teachers taking part in the study stated that they were satisfied with salaries they get; 383 $(85,5 \%)$ of teachers stated that they were not satisfied. The numbers mentioned above show that most of the teachers are not satisfied with their salaries. Likewise, several studies have claim that salary is an important variable in job satisfaction (Erol, 1989; Kağan, 2010; Kavutçu, 2016; Newstrom \& Davis, 1997; Yüksel, 2004). In this regard, there are also some studies reporting that teachers want to quit their jobs or would not want to start work at schools where they would get low salaries (Baugh and Stone, 1982). Some teachers with low salaries were reported to feel obliged to find extra jobs to earn their living (Stinebrickner, 1998). Similarly, according to the results based the job satisfaction scale, the job and salary variables shown that the teachers who are satisfied with their salaries have high job satisfaction. However, a significant difference could not be detected in among relations among individuals, administration, success, appreciation and recognition and parent student apathy variables.

When "getting support from colleagues" variable was examined, it is seen that job satisfaction is higher except sub dimensions of parent student apathy. Getting support from colleagues is one of the leading factors which increase job satisfaction (Goddard, Goddard, Miller, Larsen \& Jacob, 2010; Hellrıegel, Slocum \& Woodman, 1995; Kavutçu, 2016; Rhodes, Hollinshead \& Nevill, 2007). Those who get support from colleagues tend to have higher job satisfaction. Unrest among colleagues is undesirable and dangerous (Sharma \& Jyoti, 2009). According to Little (1996) and Nias (1996) job satisfaction level of those who fall short in getting support from colleagues tends to decrease. Especially when the unrest takes place in education sector there is even bigger danger for the school (Sharma, 2009).

Considering the data about administration variable, nearly all aspects showed a significant difference in results. There are several other studies that indicate the positive effect of administration on job satisfaction. Shourbagi \& Bakkar (2015) and Wangari \& Orodho (2014) found out that teachers who got support from administrators tend to have a higher job satisfaction level. According to Robbins (1996), when individuals are praised for the job they do their level of job satisfaction increases. Especially, in cases where administrators appreciate and help their personnel, a positive effect on performance can be found (Eren, 2000; Goddard, et al., 2010; Hellriegel, Slocum and Woodman, 1995; OECD (2014). Additionally, Van Maele \& Van Houtte (2012) assumed that administrators' support would affect job satisfaction positively. Little (1996) and Nias (1996) found that job satisfaction is negatively affected where there is no support or appraisal towards personnel.

Results of the variable "Do you think it is convenient to work at special education schools?" presented significant differences in all sub dimensions. Shourbagi \& Bakkar (2015) revealed that there is a significant relation between qualities of the job and teachers' job satisfaction. This means that the qualities of the job affect the job satisfaction (Kağan, 2005; Taşdan \& Tiryaki, 2008). From this viewpoint, it is easy to assume that being a teacher at a special education school is a tough job. That is why one should be patient and devoted to do this job (Girgin \& Baysal, 2005). Besides, according to Eskicumalı (2002), teaching is a job which cannot be done without love. Teaching should start with loving the job and loving children. A loving teacher is better in communicating with children. Those who do not love children and teaching cannot make good teachers (Eskicumal1, 2002). Within this research, teacher who stated that they loved their job and children appear to have higher job satisfaction levels. This may be because teaching at special education schools is a job which requires patience and devotion and teachers in this field are the ones who love their jobs.

According to results, there is not a significant difference based on years of work. When the sub dimensions of administration, salary, relations among individuals, success, appreciation and recognition, parent and student apathy were taken into consideration, there is not a significant difference either. However, in the sub dimensions of the job, there is a significant difference. Comparing teachers who have 1-10 years of experience with those who have more than 21, those with 1-10 years of experience have a significant difference. Moreover, there is a significant difference between those with more than 21 years and those with 11-20 years. There are several studies like Wangari \& Orodho (2014) which conclude with the same results where work experience affects job satisfaction. According to a study by Demir (2001) teachers with 1-5 years and 15 years and more work experience have significant differences in the sub dimension of relations and 1-5 and 11-15 years of work experience have significant differences on the basis of physical conditions. Mistan (2017) detected a significant relation in job satisfaction on the basis of work experience. In his study on teachers 
from Anatolian High Schools, Tan (2003) also found significant relations among teachers with 6-10, 11-15 and 16-20 years of experience. It has been observed that job satisfaction increases with work experience. Gündüz (2008) and Uras \& Kunt (2006); on the other hand, assume that work experience does not affect job satisfaction. Similarly, Akkaş (2017) and Shourbagi \& Bakkar (2015) have found that work experience does not have an effect on job satisfaction among special education school teachers. In the present research, on the basis of the job variable, it was detected that job satisfaction increases when the years in the job variable increases. This study also revealed that teachers who have 1-10 years of experience have a higher job satisfaction because they are more positive and enthusiastic in their first years of work. For the teachers with 21 years and more of work experience, the job satisfaction could be attributed to their experience and mastery in their work.

There is no significant difference between the levels of income they consider themselves at. When job satisfaction scale and its sub dimensions like the job itself, administration etc. were analysed, there is not a significant difference. When we compare sub dimension of our scale, we find a significant relation. Looking at the top and bottom income levels, there is a significant difference. When the bottom and top income levels were compared, a significant difference was seen regarding top income levels. When the bottom and middle levels were compared, there is also a significant difference on the basis of middle level. When the literature was taken into consideration, it can be seen that the income is an important variable for job satisfaction. In this regard, Yiğit (2000) found that there is a significant relation between job satisfaction and income levels. Mistan (2017) also found significant relation between job satisfaction and income levels. Tellioğlu (2004) concluded that the lowest job satisfaction level was among those who had the lowest income. Similarly, Sarpkaya (2000) detected that teachers showed the least job satisfaction in income sub dimension. Income level and the money they receive affect teachers' job satisfaction (Saiti \& Papadopoulos, 2015; Spector, 1997). AS the income increases, so does the job satisfaction (Abd-El-Fattah, 2010). In the society, the income is not only the means of meeting the needs but also the indicator of respect and honour (Sabuncuoğlu \& Tüz, 1998).

According to the findings of this study, significant relation between age and job satisfaction could not be detected. Abushaira (2012) and Shourbagi \& Bakkar (2015) did not find a significant difference on the basis of age variable, either. Yiğit (2007), in his study on special education teachers, found a minor significance of age variable in the job satisfaction. Şahin (2013) did not find a significant difference between job satisfaction and age, but Günbayı \& Tokel (2012) could detect a minor negative significance. Kavutçu (2016) identified that the highest job satisfaction was between the ages of 31-40, which was followed by above 51 years. The least job satisfaction level was detected to be between 41-50 years. Özsuer (2016) found that the highest satisfaction level on the basis of age was among the teachers between 41 and 45 . The lowest job satisfaction, according to that study, was found among the teachers between 51 and 55. Demir (2001) found that interaction, respect, holiness and morality sub dimensions represent significant differences among 21-30 and 41 and above age groups. The highest job satisfaction level was among teachers who were 41 years or older. There are various results within the literature of similar studies. According to Balc1 (1985) there is not a consistent relation between age and job satisfaction. However, working years may affect job satisfaction. Bogler (2002) stated that age variable is an important variable in job satisfaction. As there is not a significant relation between age and job satisfaction, it may be concluded that elderly teachers and younger ones work in harmony in their workplaces and share their experiences.

According to our findings teachers who work with handicapped students have an average job satisfaction. Gender variable, working years variable, age variable, income level variable do not have statistically significant relations. According to salary variable, support from colleagues, appreciation from administrators, opinion of working at a special education school can be considered to have significant relations with job satisfaction.

Further research can be carried out to find the correlation and regression of the job satisfaction among different variables.

\section{References}

Abd-El-Fattah, S. (2010). Longitudinal effects of pay increase on teachers' job satisfaction: A motivational perspective. The Journal of International Social Research, 3, 11-21.

Abushaira. M. (2012). Job Satisfaction among Special Education Teachers in Jordan. International Interdisciplinary Journal of Education, 1(3), 48-56.

Akhtara, S. N., Hashmib, M. A., \& Naqvic, S. I. H. (2010). A comparative study of job satisfaction in public and private school teachers at secondary level. Procedia Social and Behavioral Sciences, 2, 4222-4228. https://doi.org/10.1016/j.sbspro.2010.03.668

Akkaş, S. (2017). Özel eğitim ve OÇEM sınıflarında çalışan öğretmenlerin iş doyumu. Medeniyet Eğitim Araştırmaları Dergisi, 1(1), 53-65. 
Aydin, A., Uysal, S., \& Sarier, Y. (2012). The effect of gender on job satisfaction of teachers: a meta-analysis study. Procedia-Social and Behavioral Sciences, 46, 356-362. https://doi.org/10.1016/j.sbspro.2012.05.122

Balc1, A. (1985). Eğitim Yöneticisinin İş Doyumu. Doktora Tezi. Ankara Üniversitesi, Ankara.

Başaran, I. (2001). Özel eğitim kurumlarında çalışan öğretmenlerin çalışma koşulları, Ege Eğitim Dergisi, 1(1). 41-53.

Başaran, İ. E. (2000). Örgütsel davranış. Ankara: Feryal Yayınevi

Baugh, W. H., \& Stone, J. A. (1982). Mobility and wage equilibration in the educator labor market. Economics of Education Review, 2(3), 253-274. https://doi.org/10.1016/0272-7757(82)90032-2

Belias, D. (2014). Organizational culture and job satisfaction, in banking sector-a review. International Journal of Human Resources Management, 3(2), 1-20.

Bogler, R. (2002). Two profiles of school teachers: a discriminant analysis of job satisfaction. Teaching and Teacher Education, 18(6), 665-673. https://doi.org/10.1016/S0742-051X(02)00026-4

Churchill, G. A., Ford, N. M., \& Walker, O. C. (1974). Measuring the job satisfaction of industrial salesmen. Journal of Marketing Research, 11, 323-332. https://doi.org/10.2307/3151140

Clark, A. E. (1996). Job satisfaction in Britain. British Journal of Industrial Relations, 34(2), 189-217. https://doi.org/10.1111/j.1467-8543.1996.tb00648.x

Cummings, E. (1994). Stress and job satisfaction among special education teachers in urban districts in texas dissertation. (Unpublished doctoral dissertation), University of North Texas. Texas/ABD.

Demir, E. (2001). Sinıf öğretmenlerinin iş doyumunu etkileyen olası faktörler ve bu faktörler kapsamında sinlf ögretmenlerinin iş doyum düzeylerinin ölçülmesi. (Unpublished master's thesis). Gazi Üniversitesi Eğitim Bilimleri Enstitüsü, Ankara.

Duxbury, M. L., Armstrong, G. D., Drew, D. J., \& Henly, S. J. (1984). Head nurse leadership style with staff nurse burnout and job satisfaction in neonatal intensive care unit. Nurs Res., 33, 97-101. https://doi.org/10.1097/00006199-198403000-00013

Eğinli, A. T. (2009). Çalışanlarda iş doyumu: kamu ve özel sektör çalışanlarının iş doyumuna yönelik bir araştırma. Atatürk Üniversitesi İktisadi ve İdari Bilimler Dergisi, 23(3), 35-52.

Eichinger, J. (2000). Job stress and satisfaction among special education teachers: Effects of gender and social role orientation. International Journal of Disability, Development, and Education, 47, 399-412. https://doi.org/10.1080/713671153

Eren, E. (2000). Örgütlerde davranış ve yönetim psikolojisi. İstanbul: Beta Yayınevi.

Erol, E. (1989). Yönetim Psikolojisi. İstanbul: işletme iktisadi enstitüsü yayını No: 105 üçüncü baskı, İstanbul.

Eskicumal1, A. (2002). Eğitim, öğretim ve öğretmenlik mesleği, öğretmenlik mesleğine giriş. Ankara: Pegem A Yayıncilik

Faragher, E. B., Cass, M., \& Cooper, M. C. (2005). The relationship between job satisfaction and health: a meta-analysis. Occup. Environ. Med., 62, 105-112. https://doi.org/10.1136/oem.2002.006734

Filiz, Z. (2014). Öğretmenlerin iş doyumu ve tükenmişlik düzeylerinin incelenmesi. Uluslararası Yönetim İktisat ve İsletme Dergisi, 10(23), 157-171.

Ghavifekr, S., \& Pillai, N. S. (2016). The relationship between school's organizational climate and teacher's job satisfaction: Malaysian experience. Asia Pacific Educ. Rev., 17, 87-106. https://doi.org/10.1007/s12564-015-9411-8

Girgin, G., \& Baysal, A. (2005). Tükenmişlik sendromuna bir örnek: zihinsel engelli öğrencilere eğitim veren öğretmenlerin mesleki tükenmişlik düzeyi. TSK Koruyucu Hekimlik Bülteni, 4(4), 172-187.

Girgin, G., \& Baysal, A. (2005a). Zihinsel engelli öğrencilere eğitim veren öğretmenlerin mesleki tükenmişlik düzeyi ve bazı değişkenler (İzmir örneği). Pamukkale Üniversitesi Ĕgitim Fakültesi, 18, 3-15.

Goddard, R. G., Goddard, Y. L., Miller, R. J., Larsen, R., \& Jacob, R. (2010). Connecting principal leadership, teacher collaboration, and student achievement. Paper presented at the annual Institute of Education Sciences Research Conference, National Harbor, MD.

Günbayı, İ., \& Tokel, A. (2012). İlköğretim okulu öğretmenlerinin iş doyumu ve iş stresi düzeylerinin karşılaştırmalı analizi. ODÜ Sosyal Bilimler Enstitüsü Sosyal Bilimler Araştırmaları Dergisi, 3(5), 77-95. 
Gündüz, H. (2008). İlköğretim okullarında örgütsel iklim ile ögretmenlerin iş doyumu arasındaki ilişki (Gaziantep ili örneği). (Unpublished master's thesis). Gaziantep Üniversitesi Sosyal Bilimler Enstitüsü, Gaziantep.

Güneş, C. (2016). Engelli sporcularla çalı̧̧an antrenörlerin mesleki yeterliliklerinin tükenmişlik ve iş doyumu düzeylerine etkisinin incelenmesi. (Unpublished master's thesis). Sağlık Bilimleri Enstitüsü Kahramanmaraş Sütçü İmam Üniversitesi, Kahramanmaraş.

Hellriegel, D., Slocum, J. W. J., \& Woodman, R. W. (1995). Organizational Behavior. New York: West Publishing Company.

Izgar, H. (2000). Okul yöneticilerinin tükenmişlik düzeyleri (bornout) nedenleri ve bazı etken faktörlere göre incelenmesi (Unpublished doctoral dissertation). Konya: Selçuk Üniversitesi Sosyal Bilimler Enstitüsü.

Jackson, S. E., Schwab, R. L., \& Schuler, R. S. (1986). Toward an understanding of the burnout phenomenon. J. Appl. Psychol., 71(4), 630-640. https://doi.org/10.1037/0021-9010.71.4.630

Karaçam, Ö. (2017). Engelli öğrencilerin bulunduğu okullardaki yöneticilerin iş doyumlarının belirlenmesi. (Unpublished master's thesis), Pamukkale Üniversitesi Eğitim Bilimleri Enstitüsü. Denizli.

Karasar, N. (2005). Bilimsel araştırma yöntemi: Kavramlar-Illkeler-Teknikler. Ankara: Nobel Yayınevi.

Kavutçu, R. (2016). Öğretmenlerin iş doyum düzeyleri (Denizli ili merkezefendi ilçe örneği ). (Unpublished master's thesis). Pamukkale Üniversitesi Eğitim Bilimleri Enstitüsü, Denizli.

Ketheeswarani, K. (2015). Job satisfaction of teachers attached to the special education units in regular school in sri lanka. European Journal of Special Education Research, 3(1). 94-109. doi: 10.5281/zenodo.1162967.

Kumaş, V., \& Deniz, L. (2010). Öğretmenlerin iş doyum düzeylerinin incelenmesi. M.Ü. Atatürk Eğitim Fakültesi Eğitim Bilimleri Dergisi, 32, 123-139.

Little, J. W. (1996). The emotional contours and career trajectories of (disappointed) reform enthusiasts. Cambridge Journal of Education, 26, 345-359. https://doi.org/10.1080/0305764960260304

Liu, X., \& Ramsey, J. (2008). Teachers' job satisfaction: Analyses of the teacher follow-up survey in the United States for 2000-2001, Teaching and Teacher Education, 24, 1173-1184. https://doi.org/10.1016/j.tate.2006.11.010

Mastrantuono, S. (2015). Job satisfaction and attrition among special education teachers (Unpublished master's thesis). Leadership College of Education Rowan University, Glassboro, New Jersey, ABD.

Mistan, B. (2017). Özel eğitim kurumlarında çalı̧̧an öğretmenlerin iş doyumu ve mesleki tükenmişlik düzeylerinin bazı değişkenler açısından incelenmesi (Unpublished master's thesis). Necmettin Erbakan Üniversitesi Eğitim Bilimleri Enstitüsü. Konya.

Newstrom, J., \& Davis, K. (1997). Organizational Behavior, States of America. McGraw-Hill, United.

Nias, J. (1996). Thinking about feeling: The emotions in teaching. Cambridge Journal of Education, 26(3), 293-306. https://doi.org/10.1080/0305764960260301

OECD (2014). TALIS 2013 results: an international perspective on teaching and learning. OECD Publishing. https://doi.org/10.1787/9789264196261-10-en

Oshagbemi, T. (2003). Personal correlates of job satisfaction: empirical evidence from UK universities. International Journal of Social Economics, 30(12), 1210-1232. https://doi.org/10.1108/03068290310500634

Özsüer, V. S. (2016). Occupatıonal motıvatıon and job satısfactıon of Turkish secondary school teachers of English and other subjects (Unpublished master's thesis). Yedıtepe Unıversity, Eğitim Bilimleri Enstitüsü. İstanbul.

Rhodes, C., Hollinshead, A., \& Nevill, A. (2007). Changing times, changing lives: a new look at job satisfaction in two university schools of education located in the English west midlands. Research in Post-Compulsory Education, 12(1), 71-89. https://doi.org/10.1080/13596740601155421

Robins, S. P. (1996). Organizational Behaviour. New Jersey. Prentice Hall, inc.

Sabuncuoğlu, Z., \& Tüz, M. (1998). Örgütsel psikoloji. Alfa Yay. Bursa.

Şahin, İ. (1999). İlköğretim okullarında görevli ögretmenlerin iş doyum düzeyleri. (Unpublished master's thesis). Dokuz Eylül Üniversitesi, Eğitim Bilimleri Enstitüsü, İzmir.

Şahin, İ. (2013). Öğretmenlerin iş doyumu düzeyleri. YYÜ Eğitim Fakültesi Dergisi, X(I), 142-167.

Saiti, A., \& Papadopoulos, Y. (2015). School teachers' job satisfaction and personal characteristics. International Journal of Educational Management, 29(1), 73-97. https://doi.org/10.1108/IJEM-05-2013-0081 
Sarpkaya, R. (2000). Liselerde çalışan öğretmenlerin iş doyumu. Amme İdaresi Dergisi, 33, 111-124.

Sharma R. D., \& Jyoti, J. (2009). Job satisfaction of university teachers: an empirical study. Journal of Services Research, 9(2), 51-80.

Shourbagi, S. E. L., \& Bakkar, B. S. (2015). Job satisfaction among teachers of special education in Sultanate of Oman, Educational Sciences Journal, 97-114. http://search.shamaa.org/PDF/Articles/EGJes/JesVol23No4P1Y2015/jes_2015-v23-n4-p1_095-114_eng.pdf

Spector, P. (1997). Job satisfaction: application, assessment, causes and consequences. California: Sage.

Stempien, L. R., \& Loeb, D. C. (2002). Differences in job satisfaction between general education and special education teachers implications for retention. Remedial and Special Education, 23(5), 258-267. https://doi.org/10.1177/07419325020230050101

Stinebrickner, T. R. (1998). An empirical investigation of teacher attrition. Economics of Education Review, 17(2), 127-136. https://doi.org/10.1016/S0272-7757(97)00023-X

Strydom, L., Nortjé, N., Beukes, R., Esterhuyse, K., \& van der Westhuizen, J. (2012). Job satisfaction amongst teachers at special needs schools. South African Journal of Education, 32, 255-266. https://doi.org/10.15700/saje.v32n3a582

Tabachnick, B. G., \& Fidell, L. S. (2007). Using Multivariate Statistics. New York: Allyn and Bacon.

Tan, N. (2003). Anadolu Lisesi öğretmenlerinin iş doyumunu etkileyen etmenler. Yüksek Lisans Tezi, Gazi Üniversitesi Eğitim Bilimleri Enstitüsü, Ankara.

Taşdan, M., \& Tiryaki, E. (2008). Özel ve devlet ilköğretim okulu öğretmenlerinin iş doyumu düzeylerinin karşılaştırılması. Eğitim ve Bilim Education and Science, 33(147), 54-70.

Tellioğlu, A. (2004). İstanbul ili beyoğlu ilçesinde çalışan ilköğretim okulu öğretmenlerinin iş doyum düzeyleri. Yüksek Lisans Tezi, İstanbul Üniversitesi Sosyal Bilimler Enstitüsü, İstanbul.

Tran, V. D., \& Le, M. T. L. (2015). School environment factors as predictors for teachers' teaching efficacy, teacher stress and job satisfaction. International Education Research, 3(2), 28-46. https://doi.org/10.12735/ier.v3i2p28

Uras, M., \& Kunt, M. (2006). Öğretmen adaylarının öğretmenlik mesleğinden beklentileri ve beklentilerinin karşılanmasını umma düzeyleri. Pamukkale Üniversitesi Eğitim Fakültesi Dergisi, 19(1), 71-83.

Van Maele, D., \& Van Houtte, M. (2012). The role of teacher and faculty trust in forming teachers' job satisfaction: Do years of experience make a difference? Teaching and Teacher Education, 28, 879-889. https://doi.org/10.1016/j.tate.2012.04.001

Vural, B. (2004). Yetkin- ideal-vizyoner öğretmen. Hayat Yayınları. İstanbul.

Wangari, N. S., \& Orodho, J. A. (2014). Determinants of Job Satisfaction and Retention of Special Education Teachers in Primary Schools in Nairobi County, Kenya. IOSR Journal Of Humanities And Social Science, 19(6), 126-133. https://doi.org/10.9790/0837-1967126133

Waters, K. K. (2013). The relationship between principals' leadership styles and job satisfaction as perceived by primary school teachers across NSW independent schools (Unpublished doctoral dissertation). University of Wollongong, Australia.

Yaman, S. (2015). Öğretmenlerin iş doyumu düzeylerinin belirlenmesi: Ankara ili örneği (Unpublished master's thesis). Çankaya Üniversitesi, Sosyal Bilimler Enstitüsü, Çanakkale.

Yiğit, A. (2007). Özel eğitim kurumlarında çalışan öğretmenlerin iş doyumu tükenmişlik ve ruh să̆llk düzeylerinin çeşitli değişkenler açısından incelenmesi. (Unpublished master's thesis). Niğde Üniversitesi, Sosyal Bilimler Enstitüsü, Niğde.

Yüksel, Ö. (2004). İnsan Kaynakları Yönetimi. Gazi Kitapevi, Ankara.

\section{Copyrights}

Copyright for this article is retained by the author(s), with first publication rights granted to the journal.

This is an open-access article distributed under the terms and conditions of the Creative Commons Attribution license which permits unrestricted use, distribution, and reproduction in any medium, provided the original work is properly cited. 